DOI: https://doi.org/10.34069/AI/2021.40.04.21

\title{
Civil and criminal liability in the field of transport relations: the impact of the Covid-19 pandemic
}

\section{Цивільна і кримінальна відповідальність у сфері транспортних відносин: вплив пандемії Covid-19}

\author{
Written by: \\ Raisa Minchenko ${ }^{78}$ \\ https://orcid.org/0000-0003-0926-2341 \\ Pavlo Lutsyuk ${ }^{79}$ \\ https://orcid.org/0000-0001-5970-2080 \\ Dmitriy Kamensky ${ }^{80}$ \\ https://orcid.org/0000-0002-3610-2514 \\ Artem Kolodin ${ }^{81}$ \\ https://orcid.org/0000-0001-7967-2456 \\ Oleksandr Shamota ${ }^{82}$ \\ https://orcid.org/0000-0003-3335-9952
}

\begin{abstract}
The COVID-19 pandemic has changed the lives not only of many people but also significantly affected the economy of individual countries and the world economy as a whole. The world has seen a reduction in production capacity due to the closure of borders between countries and the introduction of self-isolation. The coronavirus pandemic has disrupted the usual relationship between manufacturers and users and has made a major difference in transport. Such changes have been reflected in the regulation of relations regarding civil and criminal liability for offenses in the field of transport relations in a coronavirus pandemic. With this in mind, it is important to analyze the transformations of civil and criminal liability in the field of transport due to the Covid19 pandemic. The work aims to analyze the civil and criminal liability in the field of transport relations due to the Covid-19 pandemic. The object of the study is a civil and criminal liability in the field of transport due to the Covid-19 pandemic. The subject of the study is the public relations that arise, change, and end during the prosecution of civil and criminal transport in the wake of the Covid-19 pandemic. The research methodology consists of such methods as the analytical method, historical method, method of analysis of legal documents, articles, and
\end{abstract}

\begin{abstract}
Анотація
Пандемія COVID-19 змінила життя не лише багатьох людей, але й істотно вплинула на економіку окремих країн та світову економіку загалом. У світі відбулось скорочення виробничих потужностей у зв'язку із закриттям кордонів між країнами і запровадженням режиму самоізоляції. Пандемія коронавірусу порушила звичні взаємозв'язки між виробниками i користувачами і внесла серйозні зміни у сферу транспорту. Такі зміни відобразилися i на регулюванні відносин щодо притягнення до цивільної та кримінальної відповідальності за правопорушення у сфері транспортних відносин в умовах пандемії коронавірусу. 3 огляду на це, важливо проаналізувати трансформації цивільної та кримінальної відповідальності у сфері транспортних відносин внаслідок пандемії Covid19. Метою роботи $€$ аналіз цивільної і кримінальної відповідальності у сфері транспорту внаслідок пандемії Covid-19. Об'єктом дослідження $\epsilon$ цивільна i кримінальна відповідальність у сфері транспорту внаслідок пандеміï Covid-19. Предметом дослідження є суспільні відносини, що виникають, змінюються та припиняються під час притягнення до цивільної і кримінальної відповідальності у сфері транспорту внаслідок пандемії Covid-19. Методологію дослідження складають такі методи як діалектичний метод, аналітичний метод,
\end{abstract}

\footnotetext{
${ }^{78}$ Doctor of Legal Science, Professor, Honored Lawyer of Ukraine, Chairman of the NGO "Legal Dimension", Ukraine.

${ }^{79}$ Doctor of Legal Science, Professor of the Department of Civil Law and Procedure of the National Academy of Internal Affairs, Ukraine.

${ }^{80}$ Doctor of Legal Science, Professor of the Department of Legal Courses, Berdyansk State Pedagogical University, Ukraine.

${ }^{81} \mathrm{Ph}$. D. candidate of the Department of Criminal Law of National University «Odesa Law Academy», Ukraine.

82 Master of Law of National University «Odesa Law Academy», Ukraine.
} 


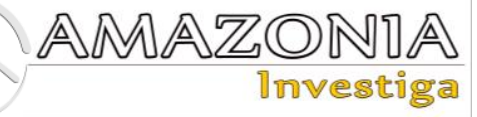

monographs, method of generalization, comparison, synthesis, and modeling. The study will analyze the changes that have taken place in the field of transport, namely the peculiarities of civil and criminal liability for violations in the field of transport during the Covid-19 pandemic, as well as clarify the problematic issues of prosecution in the field of transport and controversial aspects pre-trial settlement of conflicts by the parties. The research also identified the main trends in the transport sphere in the context of the Covid-19 pandemic and explained what changes need to be made to establish a mechanism for civil and criminal liability in the field of transport due to the Covid19 pandemic.

Keywords: court, justice, the right to a fair trial, guarantees of human rights, the Convention for the Protection of Human Rights and Fundamental Freedoms.

\section{Introduction}

Legal responsibility is a significant element of the legal regulation of public relations. Its essence is to purposefully influence the behavior of individuals through legal measures, and the goal is to protect and defend public relations from any illegal violations through coercive measures, which leads to the regulation of public relations and giving them systemicity and stability.

The consequence of the violation of legal requirements is the onset of civil or criminal liability.

In the context of the global coronavirus pandemic, several laws have been passed that have restricted transportation and recognized the impossibility of fulfilling obligations by force majeure. Such restrictions comply with the provisions of the Convention for the Protection of Human Rights and Fundamental Freedoms (United Nations, 1948), which derogate from certain rights, but only to the extent required by the provisions and provided that such measures do not conflict with other obligations under international law.

In general, the spread of coronavirus has dealt a grave blow to global logistics. The rapid spread of the COVID-19 pandemic, as evidenced by various studies. In particular, according to a study by the international team of economists of the German Economic Team (GET, Berlin) and історичний метод, метод аналізу правових документів, статей та монографій, метод узагальнення, порівняння, синтезу, моделювання. В результаті дослідження буде проаналізовано зміни, що відбулися у сфері транспорту, а саме особливості притягнення до цивільної та кримінальної відповідальності за порушення у сфері транспорту під час пандемії Covid-19, а також з'ясовано проблемні питання притягнення до відповідальності у сфері транспорту та спірні аспекти врегулювання сторонами конфліктів у досудовому порядку. Також в результаті проведеного дослідження з'ясовано головні тенденції у сфері транспорту в умовах пандемії Covid-19 та проаналізовано, які зміни необхідно прийняти задля налагодження механізму притягнення до цивільної та кримінальної відповідальності у сфері транспорту внаслідок пандемії Covid-19.

Ключові слова: цивільна відповідальність, кримінальна відповідальність, порушення у сфері транспорту, пандемія, Covid-19.

the Institute for Economic Research and Policy Consulting (IER, Kyiv), conducted in May 2020, Ukraine's GDP will shrink by $7 \%$ due to the COVID-19 pandemic, and under the pessimistic scenario, which envisages longer quarantine measures in Ukraine and more generous external challenges, the economy will shrink by even $11.2 \%$. In turn, the Kyiv School of Economics predicts that if the strict quarantine format is repeated in the spring of 2020, Ukraine's GDP will lose $0.3 \%$, and the need for financial assistance to business and the population will amount to about 23 billion hryvnias (Lukianova, \& Zaitseva, 2021).

However, despite such indicators, carriers are still held liable for non-compliance with civil and criminal liability.

No less important was the release from civil liability as a result of Covid-19 due to force majeure. As already mentioned, as a result of such restrictions, the business incurs huge losses: losses due to idle transport or transportation of many times fewer passengers and cargo. Such circumstances have given rise to discussions about the appropriateness and justification of classifying a coronavirus pandemic that has been quarantined in connection with it, or at least the decisions of public authorities and local selfgovernment in this regard as force majeure. Therefore, the question of attributing these 
circumstances to the circumstances of force majeure is quite relevant.

In addition, given that during the measures to monitor compliance with quarantine restrictions by police units as of February 18, 2021, from the beginning of quarantine: documented crimes (Article 325 of the Criminal Code of Ukraine (Law No. 2341-III, 2001)) - 56, of which: suspected - 4; sent to court -4 ; closed proceedings - 32 (Kharkiv National University of Internal Affairs6 2021).

Given the new trends in the transport sector, it is essential to analyze how civil and criminal liability in the transport sector has changed due to the Covid-19 pandemic.

\section{Theoretical Framework or Literature Review}

Civil and criminal liability in the field of transport was studied by the following scientists: Verkhovets (2008), Zakirova (2020), Kosovan (2020), Lomaka (2009), Sirko (2015), Yaremko and Lavrushina (2019), Storrs-Fox and Petrenko, (2020), Boin, Diamond, Goldsmith, and Chesny (2020). However, the transformation of civil and criminal liability in the field of transport due to the Covid-19 pandemic, scholars have not studied enough yet.

Thus, Verkhovets (2008) analyzed the issue of the scope of civil liability and drew attention to the point that the civil liability of the carrier for damage caused to the consumer of transport services has its characteristics, which are manifested in the fact that: there are various types of this liability; its occurrence is connected with obligatory grounds (illegal behavior, harm, guilt, and causation), and only in clearly defined cases can it occur in the absence of fault; the limited nature of such liability; its consequence is the application of property sanctions to the carrier. Therefore, taking into account all the characteristics of the civil liability of the carrier for breach of contractual obligations in the carriage of passengers, luggage, or cargo, the author identified it as a negative consequence, which is manifested through the statutory sanctions for the offense in the form of compensation for moral and (or) material damage or payment of penalties to restore the legal status of the passenger, which existed before the violation.

Moreover, Zakirova (2020) investigated force majeure and noted that the pandemic of the COVID-19 virus had changed. Thus, the author analyzed the work of many experts and summarized that most of them believe that, given the importance of social support during a pandemic, political parties and voters around the world understand the correctness of the decision to postpone election procedures due to force majeure caused by coronavirus COVID-19 infection. Similarly, the author noted that experts and analysts are confident about the implementation of legal instruments of force majeure to counter the negative effects of the pandemic in the economic sphere. Recognition of quarantine in Ukraine as a force majeure - is an effective mechanism to support business to protect it from mass bankruptcy and excessive penalties for overdue obligations. But the most serious challenge for Ukraine, as for many countries around the world, is to draw valuable conclusions today (from the extremely difficult situation of the pandemic) and develop effective mechanisms to create a sufficient cushion of strength and safety concerning possible unpredictable processes.

Furthermore, Kosovan also studied the issue of liability through the prism of force majeure, namely, analyzed whether the introduction of quarantine is force majeure and how it affects the effect of contracts. Thus, the researcher drew attention to the fact that on March 25, 2020, the Cabinet of Ministers of Ukraine introduced a state of emergency throughout the country. This means only the transfer of the civil protection system to the appropriate regime and does not impose any direct prohibitions on carrying out any activities. Thus, the introduction of such a regime cannot in itself be a force majeure. However, on the same day, Resolution No. 239 of the Cabinet of Ministers amended certain own acts, in particular, Resolution No. 211 of March 11, 2020 "On Prevention of the Spread of Acute Respiratory Disease COVID-19 Caused by SARS-CoV-2 Coronavirus in Ukraine". The named Resolution (which added restrictions on economic activity) in connection with the quarantine provided by the Law of Ukraine of March 17, 2020, No 530-IX, was supplemented by the list of force majeure circumstances provided in Article 141 of the Law of Ukraine "On Chambers of Commerce and Industry in Ukraine". Separately, the author draws attention to the fact that there are no restrictions on freight and why all these details are essential. A party to a contract may invoke force majeure only if its existence deprives such a party of the opportunity to fulfill its obligations. A deprivation of opportunity must be understood as a direct and direct causal link between quarantine and the inability to perform an obligation. For example, if you have an obligation under the supply 


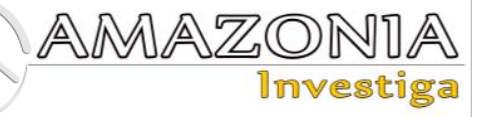

contract to deliver the goods, then there is no direct ban on the set of works required for its implementation, so there is no reason to refer to quarantine as force majeure. Similarly, quarantine is not a force majeure for monetary obligations. The direct link between force majeure and payment should be understood as circumstances that directly deprive the payer of the opportunity to do so, such as the shutdown of the banking system in Ukraine. In this case, the lack of funds from the payer is not a force majeure.

Additionally, Lomaka (2009) investigated the scope of liability for non-performance and improper performance of obligations under contracts of carriage of goods by rail. The change in socio-economic relations has eliminated the planned nature of the contract of carriage. The principle of limited liability had to be revised in a new way; to justify its application in the conditions of free economic activity because transportation is a business activity of transport organizations and must comply with all the principles of business activity. Thus, the author pointed out that the establishment of the principle of limited liability is not fair in the context of the unity of transportation and supply. The insecurity of the cargo (goods) can be reimbursed to the consignor (supplier) only within the amount of actual damage, and the supplier is liable to the buyer in full. Due to the above reasons, it is not economically advantageous for the consignee (buyer) to address claims to the carrier and demand his liability. This is all the more true that the release of the railway carrier from liability, primarily under the rules of Art. 111 of the Charter of the railways of Ukraine (Resolution No. 457, 1998), easily achievable, and the procedure for imposing liability on the railway carrier is complex; a refutation of the evidence provided by the railway carrier is extremely difficult. The limited liability of the carrier indirectly encourages the recipient to transfer losses from the carrier to the sender and release the former from liability in general.

Besides, Yaremko and Lavrushina (2019) analyzed the responsibility of road carriers within the domestic service and concluded that today there is a need to find a solution that can be beneficial for all participants in domestic transport. An example of solving this problem in other countries, as demonstrated in this article, is the practice of limiting the carrier's liability to a defined limit, depending on the weight of the goods being transported. In any case, when deciding on limiting the carrier's liability and changing the national legislation of Ukraine, it is necessary to take into account various factors of influence, primarily economic (market price, the solvency of Ukrainian carriers, etc.), which can contribute to a reasonable distribution of risks among all business participants, and the improvement of the domestic transportation market of Ukraine.

In the civilist literature, Sirko (2015) expresses a position on the need to hold the carrier fully liable for breach of the obligation to carry luggage by rail. In the dissertation research "Liability of participants of civil legal relations arising from the carriage of goods, passengers, and luggage by rail under the laws of Ukraine" he proposes, instead of an exclusive penalty (which applies in case of bringing the carrier to justice for breach of luggage by rail), to use a penalty, which would provide an opportunity to recover not only the penalty itself but also the amount of damages.

In addition, the publications of various publishers and organizations were analyzed, including the international experience of overcoming the economic consequences of the pandemic, the impact of Covid-19 on aviation and tourism, the recognition of quarantine as force majeure (force majeure), and the trends in the sphere of transport in 2020-2021. (Asian Development Bank, 2021; Ambroziak, 2020; Retail.ru, 2020; European Business Association, 2020; Association of International Road Carriers of Ukraine, 2020)

Thus, from the above analysis of the literature, it can be concluded that civil and criminal liability in the field of transport due to the Covid-19 pandemic has been insufficiently studied, and, therefore, there is a need to analyze in more detail the transformation of liability due to quarantine restrictions.

\section{Methodology}

The study of civil and criminal liability in the field of transport due to the Covid-19 pandemic used such methods as the analytical method, historical method, method of analysis of legal documents, articles, and monographs, method of generalization, comparison, synthesis, and modeling.

Thus, the analytical method allowed to consider in detail the regulations of both international and Ukrainian regulation of liability in the field of transport. The method also helped to analyze statistics on the loss of the transport industry due to the Covid-19 pandemic, as well as the work 
concerning this topic of domestic and foreign scholars.

The method of analysis of legal documents, articles, and monographs was used in the study of legislation and scientific works of scientists to make a complete comparison. Thanks to this method it was possible to carry out a comprehensive study of regulations, namely: the Convention for the Protection of Human Rights and Fundamental Freedoms (United Nations, 1948); the Constitution of Ukraine (Law No. 254K/96-BP, 1996); Criminal Code of Ukraine (Law No. 2341-III, 2001); Code of Ukraine on Administrative Offenses; Civil Code of Ukraine (Law No. 435-IV, 2003); On prevention of the spread of acute respiratory disease COVID-19 caused by coronavirus SARS-CoV-2 on the territory of Ukraine (Resolution No. 211, 2020); On Amendments to the Law of Ukraine "On Protection of the Population from Infectious Diseases" on Prevention of Coronavirus Disease (COVID-19) (Law No. 555-IX, 2020); On Amendments to Certain Legislative Acts of Ukraine Aimed at Preventing the Occurrence and Spread of Coronavirus Disease (COVID-19) (Law No. 530-IX, 2020); On Chambers of Commerce and Industry in Ukraine (Law No. 671/97-BP, 1997); Regulations for certification by the Chamber of Commerce and Industry of Ukraine and regional chambers of commerce and industry of force majeure (force majeure) (Decision No. 44(5), 2014).

The historical method allowed us to analyze the prosecution for violations in the field of transport in different periods and different historical conditions.

The generalization method allowed to unite the general provisions on responsibility in the field of transport and its regulation in Ukraine, taking into account various international legal acts.

The method of comparison allowed us to compare the prosecution in the field of transport in Ukraine and foreign countries. The method of synthesis was used to study certain regulations on prosecution in the field of transport, and to further generalize the provisions of such regulations.

The use of the modeling method allowed to model how civil and criminal prosecution in the field of transport will be carried out in the future and to develop legal acts for effective regulation of the researched issue.

\section{Results and Discussion}

General provisions on civil and criminal liability in the field of transport

Before analyzing the transformations of civil and criminal liability in the field of transport due to the Covid-19 pandemic, let us separate the general provisions on civil and criminal liability in the field of transport.

Responsibility in the field of transport is primarily the responsibility of freight forwarders, carriers, shippers, and consignees. Damaged, lost, and stolen goods, unfortunately, are a common and widespread problem in the transportation of goods. And in the conditions of stopping and complication of a transport connection, the question of responsibility sharply arises.

In the case of cross-border transit, the responsibility for the safety of the goods is governed primarily by the relevant international agreements. At the same time, the norms of the current legislation of Ukraine are applied to domestic transportation. Article 924 of the Civil Code of Ukraine (Law No. 435-IV, 2003) provides that the carrier is responsible for the safety of cargo, luggage, mail from the moment of their acceptance for transportation and delivery to the recipient unless it proves that the loss, shortage, damage, or damage to cargo, luggage, mail occurred due to circumstances could not prevent and the elimination of which did not depend on him. The carrier is liable for loss, shortage, damage, or damage to the cargo, luggage, mail accepted for transportation in the amount of actual damage unless he proves that it was not his fault.

Therefore, the legislation of Ukraine presupposes the responsibility of the carrier for the safety of the goods from the moment of acceptance until delivery to the consignee. At the same time, the limits of the value of the carrier's liability are limited by the price of the damaged or lost cargo or the amount by which its value has decreased.

On the one hand, the absence of marginal liability of the carrier is a reasonably rational and economically justified decision because who (the carrier and/or his insurance company) must compensate for all damages caused to the owners of the goods. But, often, such unresolved causes several problems.

In conclusion, it should be noted that freight is a business that involves constant high risks. 


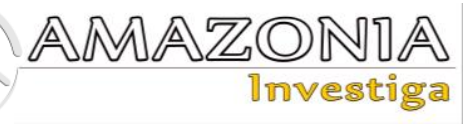

Uncontrolled problems occur during transportation, which can cause damage or loss of cargo. In most cases, such risks are borne by the carrier, who must reimburse the entire cost of lost, damaged, or stolen goods (whether cheap ballpoint pens or expensive mobile phones). Often the carrier cannot cover a large amount, the limit of which is not provided by Ukrainian law, which harms the interests of all parties involved, including freight forwarders, carriers, shippers, and consignees. Thus, today there is a need to find a solution that can be beneficial to all participants in domestic traffic. An example of solving this problem in other countries is the practice of limiting the liability of the carrier to a certain amount, depending on the weight of the goods transported.

In addition, it is somewhat interesting to prosecute for violating quarantine measures in the field of transport. Thus, in Ukraine, special restrictions were introduced in the operation of public transport and minibusses (no more than 10 passengers can be transported at a time). Law enforcement agencies monitored the provision of existing restrictions to prevent the spread of outbreaks of infection following the Law of Ukraine "On Amendments to Certain Legislative Acts of Ukraine Aimed at Preventing the Outbreak and Spread of Coronavirus (COVID19)" (Law No. 530-IX, 2020), which provides for administrative and criminal liability for violations quarantine regime.

In addition, the criminal liability provided for in Article 325 of the Criminal Code of Ukraine (Law No. 2341-III, 2001) has been strengthened. Thus, violation of the rules and regulations established to prevent epidemic and other infectious diseases, as well as mass noncommunicable diseases (poisoning) and control them, if such actions have caused or may have caused the spread of these diseases - is punishable by a fine of one thousand to three thousand tax-free minimum incomes (UAH $17,000-51,000)$ or arrest for up to 6 months, or restriction of liberty for up to 3 years, or imprisonment for up to 3 years.

Thus, the responsibility in the field of transport has its characteristics, given the subjective component of the offense and the specifics of transportation.

Features of civil and criminal prosecution in the field of transport due to the Covid-19 pandemic
Bringing to civil and criminal liability has its own characteristics. Thus, in the context of the Covid-19 pandemic, release from civil liability is possible by proving the existence of force majeure.

The definition of force majeure exists exclusively in the Law of Ukraine "On Chambers of Commerce and Industry in Ukraine" (Law No. 671/97-BP, 1997): exceptional and unavoidable circumstances that objectively prevent the fulfillment of obligations under the terms of the contract (agreement, contract, etc.), obligations under the law and other regulations. Therefore, the search for the consequences of force majeure should be carried out in the concluded contracts, which usually contain not only a list of force majeure circumstances but also the consequences of their occurrence. There are cases when the existence of force majeure relieves the party of the obligation to perform obligations under the contract, although sometimes provides that in the event of force majeure for a longer period of time may lead to termination of the contract and return of the parties. However, even in this case, you will have to pay for the goods actually delivered or services provided, as it is not possible to return them.

Let us consider the terms of force majeure and the example of international arbitration. Thus, today there are quite a few trade associations in the world that are designed to promote the development of trade in raw materials. Trade associations are a kind of business platform within which experience is exchanged (through conferences, seminars, networking, etc.), standard agreements are created, disputes between companies are resolved (in arbitrations administered by associations), etc. In other words, trade associations arise on the initiative of the business itself and function to support and develop it. Today, well-known associations such as GAFTA (Grain and Feed Trade Association, 2021) and FOSFA (Federation of Oils, Seeds and Fats Associations Ltd, 2021) are based in England. The force majeure terms in the GAFTA and FOSFA contracts stipulate that the fulfillment of obligations may be postponed for a certain period, after which it will be automatically terminated if these conditions do not cease to exist. Furthermore, quite often, to be able to refer to force majeure, the contract provides for the sending of notice at a specified time. Such an obligation is significant, and failure to comply with it in certain cases may result in the party not being able to invoke force majeure as a basis for release from liability. 
If the contract does not provide for force majeure separately, you should refer to the provisions of Art. 17 of the Civil Code of Ukraine (Law No. 435-IV, 2003), in which force majeure is defined as force majeure, but which at the same time exempts from liability for failure to fulfill obligations in connection with such circumstances.

In this case, the provisions of the Civil Code of Ukraine (Law No. 435-IV, 2003) contain provisions that such a release from liability occurs unless otherwise provided by contract. The next step is to obtain confirmation of the force majeure circumstances, which is the relevant certificate. In this case, depending on the specific reason for this, the options may be different. However, in any case, it is necessary to contact the counterparty, because force majeure itself, as well as the fact that it makes it impossible to fulfill a specific obligation, must be proved, it is possible to agree to amend the contract without any evidence and certificates from the Chamber of Commerce and Industry (CCI).

It should be understood that force majeure is used only when it affects the performance of a specific obligation. For example, the contract stipulates the supply by rail (and otherwise). At the same time, force majeure will work if freight rail transportation through the territory of Ukraine is banned for the period of quarantine. Force majeure exempts from liability (fines, penalties, etc.) but not from the fulfillment of obligations under the contract. Force majeure is not: financial and economic crisis, rising exchange rates, breach of debtors' debtors, lack of goods on the market to meet obligations, lack of money (paragraph 3.2 of the Regulations of the CCI of Ukraine and regional CCI force majeure, approved by the decision of the Presidium of the CCI of Ukraine dated December 18, 2014, No. $44(5)$, even when it is caused by quarantine.

Trends in transport in the wake of the Covid-19 pandemic, affecting civil and criminal liability for offenses

Although the bans were considered a temporary pandemic, many acknowledge that the crisis caused by the spread of the coronavirus will be long-term (Kharytonov, Kharytonova, Kolodin, \& Tkalych, 2020). Thus, to combat the coronavirus, human civilization must mobilize all available resources and develop a common strategy of action, which should be based on a new ethics of relations in the plane of «manman» and «man-state» (Tkalych, Safonchyk, \& Tolmachevska, 2020).

It should be noted, that as a result of the Covid19 pandemic in the field of transport, the following trends are observed:

1. Reduction of freight flow globally and locally. The reasons are obvious: closing borders; mass closure of outlets; isolation of the population; state of fear and uncertainty among consumers.

2. Lack of simple and clear «rules of the game» in quarantine conditions for representatives of the transport sector.

However, within countries, statistics give the opposite, consider how the situation has changed in the logistics market on the example of the Russian Federation (Table 1). According to the data provided, we can see that due to the pandemic, the market for transportation services has only expanded.

Table 1.

The logistics market of the Russian Federation, 2019-2021. Data provided by Eurostatica. (2021).

\begin{tabular}{ll}
\hline Before the Covid-19 pandemic (2019-2020) & After the Covid-19 pandemic (2021) \\
\hline 1.294 million trucks & 1.447 million trucks \\
560 thousand freight and logistics companies & 630 thousand freight and logistics companies \\
\hline
\end{tabular}

However, rapid adaptation to changing conditions will help the transport sector to return to its previous state. It is obvious that even in the post-crisis period, trends will continue that will have an impact on the transport sector, including responsibility in this area (Retail.ru, 2020).
Trend 1. Dumping in the market of transport services and withdrawal from the market of weak players. Every year the struggle for the choice of the client grows. Such a struggle results in product improvement and the withdrawal of weak players from the market. Thus, according to the socio-economic impact assessment of COVID-19, conducted by the UN Development 


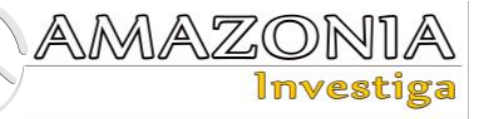

Program in October 2020 in Ukraine, more than $10 \%$ of small and medium enterprises, due to the pandemic, are on the verge of bankruptcy and may soon close their business (Lukianova, \& Zaitseva, 2021).

Trend 2. Development of collaborations, cooperatives, and integration of services. Players are increasingly coming together to share each other's services. For example, companies refuse to purchase and use the services of partners.

Trend 3. Secure courier delivery. Safe courier delivery is delivery that provides a safe way to deliver goods. Thus, at present, the contact of drivers with employees of warehouses, customs authorities, and other persons with whom it is necessary to contact has been reduced to a minimum. This approach has a positive effect on the company's perception of the company and prevents the spread of coronavirus infection.

Trend 4. Introduction of the newest ITtechnologies. A number of companies have introduced automatic equipment for loading and unloading, trailers, GPS. For example, in 2014, Deutsche Post DHL signed an agreement with the Escher Group, which allowed DHL to use its network efficiently, upgrade technology and introduce easier delivery in Germany (Trade Master Groupб 2017).

Raben Group focuses on digitalization on many levels, from physical processes to office robotics with RPA (Robotic process automation). In the field of automation, advanced IT solutions are being implemented, such as platforms that provide information to customers automatically and display ETA (expected arrival time). In the field of warehouse automation and robotics, implementation processes include the use of load measuring devices, autonomous or semiautomated loaders, "cobotic" manipulators, sensors of the Internet device control system (IoT), and many other solutions that increase the efficiency of warehousing and transportation processes. In the field of RPA, emphasis should be placed on the implementation of robotic software that supports or replaces user work in special applications (WMS / TMS / FK) or on the interface of various IT systems (Raben group, 2021).

Trend 5. Transportation through the use of a mobile device. Transportation using mobile applications is becoming more popular. This service provides a full range of services with a supply chain through the use of a mobile device. However, such a service is already available from Dostavista (2021), Peshkariki (2021), Garantbox (2021), Yandex Delivery (2021), etc.

Trend 6. Development of domestic transportation. The pandemic gave impetus to the development of domestic production. The threat of closing the borders in the event of the next wave of the pandemic leads to the fact that some of the resources, goods, products that were previously purchased elsewhere, manufacturers will try to produce in their own country. For example, in the postal logistics market, Ukrposhta rebranded and was able to compete with Nova Poshta. Ukrposhta increased turnover by $+15 \%$ (Trade Master Group 2017).

\section{Conclusions}

As a result of the study, the features of civil and criminal liability in the field of transport due to the Covid-19 pandemic were analyzed and the following conclusions were made:

1. The Covid-19 pandemic has a global and local impact on freight traffic. The reasons are obvious: closing borders; mass closure of outlets; isolation of the population; the state of fear and uncertainty among consumers, and the lack of simple and clear rules of the game in quarantine for representatives of the transport sector.

2. Today, there is a need to find a solution that can be beneficial to all participants in domestic traffic. An example of solving this problem in other countries is the practice of limiting the liability of the carrier to a certain amount, depending on the weight of the goods transported.

3. In the field of transport, it is possible to be prosecuted for violating quarantine measures. Thus, in Ukraine, certain restrictions were introduced in the operation of public transport and minibusses (no more than 10 passengers can be transported at a time). Violation of the established requirements may result in criminal prosecution.

4. The force majeure conditions in the GAFTA and FOSFA contracts provide that the performance of the obligations may be suspended for a certain period, after which it will be automatically terminated if these conditions do not cease to exist. Also, quite often, to be able to refer to force majeure, the contract provides for the sending of notice at a specified time. Such an obligation is significant, and failure to comply with it, in several cases, may result in the party not 
being able to invoke force majeure as a basis for release from liability.

5. Exemption from civil liability is possible provided that force majeure is proved. But if the contract does not provide for force majeure separately, it is worth referring to the provisions of Art. 17 of the Civil Code of Ukraine, in which force majeure is defined as force majeure, but which at the same time release from liability for failure to fulfill obligations in connection with such circumstances.

Regarding further scientific research, it is necessary to pay attention to the possibility of resolving issues related to the signing of international agreements to mitigate liability in the field of transport and international transportation.

\section{Bibliographic references}

Ambroziak, N. (2020). Quarantine and force majeure: how does it work? Factor Media. Recovered from https://i.factor.ua/ukr/journals/nibu/2020/april/is sue-29/article-107889.html

Asian Development Bank. (2021). Impact of Covid-19 on aviation and tourism in Central Asia Regional Economic Cooperation. Mandaluyong: Asian Development Bank. ISBN 978-92-9262103-2. Recovered from https://www.adb.org/sites/default/files/publicati on/677216/impact-covid-19-carec-aviationtourism-ru.pdf

Association of International Road Carriers of Ukraine. (2020). Regarding the recognition of quarantine as force majeure (force majeure circumstances). Recovered from http://www.asmap.org.ua/index1.php?idt=66098 Boin, K., Diamond, T., Goldsmith, P., \& Chesny, D. (2020). COVID-19 - Implications for contracts governed by English law. Debevoise \& Plimpton. Recovered from https://www.debevoise.com/-

/media/files/insights/publications/2020/03/2020 0323-covid2019-and-its-impact-on-english-lawc.pdf

Decision No. 44(5), Regulations for certification by the Chamber of Commerce and Industry of Ukraine and regional chambers of commerce and industry of force majeure (force majeure). Bulletin of the Verkhovna Rada of Ukraine, Kyiv, Ukraine, December 18, 2014. Recovered from

https://zakon.rada.gov.ua/rada/show/v004457114\#Text

Dostavista. (2021). The official web-site. Recovered from https://dostavista.ru.
European Business Association. (2020). International experience in overcoming the economic consequences of the pandemic. Recovered from https://eba.com.ua/mizhnarodnyj-dosvidpodolannya-ekonomichnyh-naslidkivpandemiyi/

Eurostatica. (2021). Logistics market statistics and expertise. Recovered from http://eurostatica.com/.

FOSFA (Federation of Oils, Seeds and Fats Associations Ltd). (2021). The official web-site. Recovered from https://www.fosfa.org/.

GAFTA (Grain and Feed Trade Association). (2021). The official web-site. Recovered from https://www.gafta.com/.

Garantbox. (2021). The official web-site. Recovered from https://garantbox.ru

Kharkiv National University of Internal Affairs. (2021). Current issues of business entities in the context of the Covid-19 pandemic. Kharkiv: Kharkiv National University of Internal Affairs. Recovered from http://dspace.univd.edu.ua/xmlui/bitstream/hand le/123456789/10207/Aktualni\%20pytannia\%20 diialnosti\%20subiektiv\%20hospodariuvannia\% 20v\%20umovakh\%20pandemii\%20COVID19_2021.pdf?sequence $=1$ \&isAllowed=y Kharytonov, E., Kharytonova, O., Kolodin, D., \& Tkalych, M. (2020). The Covid-19 Pandemic and the Rights of the Individual in Terms of Private and Public Law. Ius Humani. Law Journal, 9(2), 225-250.

DOI: https://doi.org/https://doi.org/10.31207/ih.v9i2.2 53

Kosovan, A. (2020). Is the introduction of quarantine force majeure and how does it affect the validity of contracts? Agravery. Recovered from

https://agravery.com/uk/posts/author/show?slug =ci-e-vvedenna-karantinu-fors-mazorom-ta-akvin-vplivae-na-diu-dogovoriv

Law No. 2341-III, Criminal Code of Ukraine. Bulletin of the Verkhovna Rada of Ukraine, Kyiv, Ukraine, April 5, 2001. Recovered from https://zakon.rada.gov.ua/laws/show/2341-

14/conv\#n2649

Law No. 254к/96-BP, Constitution of Ukraine. Bulletin of the Verkhovna Rada of Ukraine, Kyiv, Ukraine, June 28, 1996. Recovered from https://zakon.rada.gov.ua/laws/show/254\%D0\% BA/96-\%D0\%B2\%D1\%80\#Text.

Law No. 435-IV, Civil Code of Ukraine. Bulletin of the Verkhovna Rada of Ukraine, Kyiv, Ukraine, January 16, 2003. Recovered from https://zakon.rada.gov.ua/laws/show/43515\#Text.

Law No. 530-IX, On amendments to some legislative acts of Ukraine aimed at preventing 


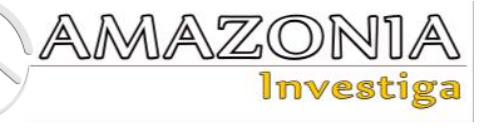

the occurrence and spread of coronavirus disease (COVID-19). Bulletin of the Verkhovna Rada of Ukraine, Kyiv, Ukraine, March 17, 2020. Recovered from

https://zakon.rada.gov.ua/laws/show/530-

20\#Text

Law No. 555-IX, On Amendments to the Law of Ukraine "On Protection of the Population from Infectious Diseases" on Prevention of the Spread of Coronavirus Disease (Covid-19). Bulletin of the Verkhovna Rada of Ukraine, Kyiv, Ukraine, April 13, 2020. Recovered from https://zakon.rada.gov.ua/laws/show/555-20.

Law No. 671/97-BP, On chambers of commerce and industry in Ukraine. Bulletin of the Verkhovna Rada of Ukraine, Kyiv, Ukraine, December 2, 1997. Recovered from https://zakon.rada.gov.ua/laws/show/671/97-

вp\#Text

Lomaka, V. (2009). The amount of liability for non-performance and improper performance of duties under contracts of carriage of goods by rail. Entrepreneurship, Economy and Law, 10, 101-105.

http://dspace.nbuv.gov.ua/handle/123456789/15 751

Lukianova, N., \& Zaitseva, O. (2021). The coronavirus pandemic: legal mechanisms to protect the labor and social rights of workers. Kyiv: Social Initiatives for Occupational Health and Safety" (LHSI). Recovered from http://rv.dsp.gov.ua/wp-

content/uploads/2021/02/lhsi_pandemya_koron avrusu.pdf.

Peshkariki. (2021). The official web-site. Recovered from https://peshkariki.ru.

Raben group. (2021). New realities of the logistics industry 2020. From the perspective of the Raben group. Recovered from https://ukraine.raben-

group.com/novini/detalnishe/novi-realiji-

logistichnoji-galuzi-2020-z-tochki-zoru-grupiraben.

Resolution No. 211, On prevention of the spread on the territory of Ukraine of the acute respiratory disease Covid-19 caused by the coronavirus SARS-CoV-2. Bulletin of the Verkhovna Rada of Ukraine, Kyiv, Ukraine, March 11, 2020. Recovered from https://zakon.rada.gov.ua/laws/show/211-2020$\% \mathrm{D} 0 \% \mathrm{BF}$.
Resolution No. 457, About the statement of the Charter of railways of Ukraine. Bulletin of the Verkhovna Rada of Ukraine, Kyiv, Ukraine, April 6, 1998. Recovered from https://zakon.rada.gov.ua/laws/show/457-98$\%$ D0\%BF\#Text.

Retail.ru. (2020). Logistics Trends 2020-2021: Impact of the COVID-19 Pandemic on Transportation. Recovered from https://www.retail.ru/articles/logisticheskietrendy-2020-2021-goda-vliyanie-pandemiicovid-19-na-perevozki/

Sirko, R. (2015). Liability of participants of civil legal relations arising from the carriage of goods, passengers and luggage by rail, under the laws of Ukraine (dis. ... cand. jurid. Ciencias) National University "Odesa Law Academy". Odesa. Recovered from http://dspace.onua.edu.ua/handle/11300/811

Storrs-Fox, P., \& Petrenko, A. (2020). COVID 2019: Implications for Transport and Logistics. Sea News. Recovered from https://seanews.ru/2020/04/07/ru-covid-2019posledstvija-dlja-transporta-i-logistiki/ Tkalych, M., Safonchyk, O., \& Tolmachevska, Y. (2020). Private Law and human rights: New realities. DIXI, 32, 1-12. DOI: https://doi.org/10.16925/2357-5891.2020.02.04 Trade Master Group. (2017). Analysis of the market of logistic services in ukraine. Trends, challenges and opportunities. Recovered from https://trademaster.ua/articles/312595.

United Nations. (1948). Universal Declaration of Human Rights. Recovered from https://www.un.org/en/universal-declarationhuman-rights/.

Verkhovets, A. (2008). On the question of the scope of civil liability. Kyiv: Obrii.

Yandex Delivery. (2021). The official web-site. Recovered from https://eda.yandex/.

Yaremko, V., \& Lavrushina, V. (2019). Who is at risk? Responsibility of road carriers within the domestic service. European Business Association. Recovered from https://eba.com.ua/hto-ryzykuye-vidpovidalnistavtomobilnyh-pereviznykiv-u-mezhah-

vnutrishnogo-spoluchennya/

Zakirova, S. (2020). Force majeure: what has changed the pandemic of the virus COVID-19? Public opinion on lawmaking, 5 (190), 4-10. Recovered from http://nbuviap.gov.ua/images/dumka/2020/5.pdf 